DOI: https://doi.org/10.34069/AI/2021.44.08.4

How to Cite:

Bryhinets, O., Halus, O., \& Ryzhuk, I. (2021). Prospects of legal regulation of contractual relations in the sphere of lobbying management as a counteraction to corruption at the municipal level. Amazonia Investiga, 10(44), 38-47. https://doi.org/10.34069/AI/2021.44.08.4

\title{
Prospects of legal regulation of contractual relations in the sphere of lobbying management as a counteraction to corruption at the municipal level
}

\section{ПЕРСПЕКТИВИ ПРАВОВОГО РЕГУЛЮВАННЯ ДОГОВІРНИХ ВІДНОСИН У СФЕРІ УПРАВЛІННЯ ЛОБІЮВАННЯМ ЯК ПРОТИДІЯ КОРУПЦИЙНИМ ЯВИЩАМ НА МУНІЦИПАЛЬНОМУ РІВНІ}

\author{
Received: July 5, 2021
}

Accepted: August 18, 2021

\author{
Written by: \\ Oleksandr Bryhinets ${ }^{16}$ \\ https://orcid.org/0000-0003-4058-7566 \\ Olena Halus ${ }^{17}$ \\ https://orcid.org/0000-0002-5474-3323 \\ Iryna Ryzhuk ${ }^{18}$ \\ https://orcid.org/0000-0002-5916-3774
}

\begin{abstract}
The objective of the article is a comprehensive analysis of the problem of interpretation of contractual relations and their management into the legal field of the national legislation to achieve the significant reduction of corruption at the municipal level on the territory of our country. To achieve this objective, a set of philosophical-worldview, general scientific (analysis, synthesis) and special-scientific methods (systemic, structural-functional, comparative-legal) have been used. It is proved that lobbying is a subjective factor that affects the process of municipal legal regulation. Emphasis is placed on the expediency of introducing the contractual form of regulation of relations on lobbying management decisions at the municipal level. The contract on lobbying at the municipal level is defined as a multilateral agreement between the customer, lobbyist and the body of local government, which has a public-law character, establishes contractual rules of law on lobbying to influence the process of adopting normative municipal-legal acts. It is concluded that it is extremely important to organize and regulate lobbying in any country in the world,
\end{abstract}

\begin{abstract}
Анотація
Метою статті є комплексний аналіз проблеми інтерпретації договірних відносин та управління ними у правове поле вітчизняного законодавства для досягнення значного зниження корупційних явищ на муніципальному рівні на території нашої держави. Для досягнення цієї мети використовувались комплекс філософськосвітоглядних, загальнонаукових (аналіз, синтез) та спеціально-наукових методів (системний, структурно-функціональний, порівняльно-правовий). Доведено, що лобіювання виступає суб'єктивним чинником, який впливає на процес муніципально-правового регулювання. Наголошено на доцільності впровадження договірної форми регулювання відносин щодо лобіювання прийняття управлінських рішень на муніципальному рівні. Визначено договір про лобіювання на муніципальному рівні як багатосторонній договір між замовником, лобістом та органом місцевого самоврядування, який має публічно-правовий характер, встановлює договірні норми права щодо лобістського впливу на процес
\end{abstract}

\footnotetext{
${ }^{16}$ Doctor of Law, Associate Professor, Professor of Constitutional, Administrative and Financial Law Department, Leonid Yuzkov Khmelnytskyi University of Management and Law, Khmelnytskyi, Ukraine.

${ }^{17}$ Ph.D., Associate Professor, Associate Professor of Constitutional, Administrative and Financial Law Department, Leonid Yuzkov Khmelnytskyi University of Management and Law, Khmelnytskyi, Ukraine.

${ }^{18}$ Ph.D., Associate Professor of Constitutional, Administrative and Financial Law Department, Leonid Yuzkov Khmelnytskyi University of Management and Law, Khmelnytskyi, Ukraine.
} 


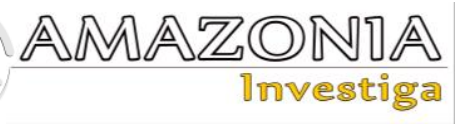

because if this phenomenon cannot be completely eradicated, it must be regulated from the legal point of view, which, in the end, will significantly reduce the level of corruption in the society.

Key words: corruption, lobbying management, lobbying agreement, administrative agreement, lawmaking, municipal-legal acts.

прийняття нормативних муніципальноправових актів. Зроблено висновки про те, що вкрай важливим $\epsilon$ питання організації та впорядкування лобіювання у будь-якій державі світу, адже, якщо дане явище не можна викорінити повністю, то його потрібно впорядкувати 3 правової точки зору, що, у підсумку, дасть можливість значно знизити рівень корупційних проявів у суспільстві.

Ключові слова: корупція, управління лобіюванням, договір про лобіювання, адміністративний договір, правотворча діяльність, муніципально-правові акти.

\section{Introduction}

At present, our state faces rather difficult challenges, and to solve them it is necessary to implement a number of ambiguous and sometimes unpopular solutions. One such way is to legalize lobbying. During the period of active fight against the COVID-19 pandemic, no one an individual, an organization, the state as a whole - has all the information necessary to solve complex and diverse problems facing the state (Lazur, Karabin, Martyniuk, Bukhanevych \& Kanienberh-Sandul, 2020; Lytvyn, Zinchenko, Basarab, Andrusiv \& Ryzhuk, 2021). After all, even after making the most effective decision, it is not always possible to properly implement it in practice. That is, it is necessary to stimulate the development of partnership relations both at the national level and at the municipal level. The former principle of minimal state intervention and the slogan "the less centralized management, the better, and the problems will be solved by themselves", gradually loses relevance and reveals a great need for cooperation between government officials and other influential subjects (Kooiman, 2001; Bryhinets, Svoboda \& Shevchuk \& Kotukh \& Radich, 2020).

An important factor in lobbying at the municipal level is the fact that those who influence local governments have many contacts with the latter, because they are in a fairly small area, such as one city, and their interaction is due to the commonality of those urgent problems that need to be addressed, both to ensure the well-being of the city, decent standard of living for citizens, and so that local authorities themselves can address both tactical and strategic issues for the overall development of the city.

Lobbying at the municipal level serves as a means of ensuring compromise and developing the right priorities in the management decision-

making process. Municipal lobbying is brighter than state-wide lobbying, able to reflect the true structure of the interests of financial and industrial circles, social groups of population and other influential groups.

The article argues the approach according to which the importance of legal consolidation of lobbying as a counteraction to the spread of corruption at the municipal level at this stage of state development is determined. The objective of the article is a comprehensive analysis of the problem of interpretation of contractual relations and their management into the legal field of the national legislation to achieve the significant reduction of corruption at the municipal level on the territory of our country.

\section{Theoretical Framework or Literature Review}

Modern Western political science pays considerable attention to the problems of studying the peculiarities of the practical activities of lobbyists, the study of lobbying as a political institution. Among the important scientific developments in this area are the works of K. Hunter, who in his works carried out a thorough analysis of the impact of lobbying on economic processes in the state (Hunter, 2001); $\mathrm{H}$. Brown, who identified the issue of lobbying under the conditions of economic crisis and ensuring the rights and freedoms of citizens in transition period (Brown, 2012).

The issue of lobbying of making government decisions at the municipal level and its correlation with corruption offenses remains insufficiently researched. The important scientific developments of some aspects of the correlation between lobbying and corruption were studied by Matthew Jenkins and Suzanne 
Mulcahy. Very interesting are their positions, that while anti-corruption legislation has become more standardised around the world, lobbying legislation is a notable exception to this trend, and that the two main measures to prevent corrupt forms of lobbying are: selfregulation and regulatory regimes (Jenkins \& Mulcahy, 2018).

The reasons of the impact of corruption on the economic development of the country were also studied separately (Savchenko L. et al., 2018); legal relations in the field of donation with the participation of civil servants and their relatives (Kolomoets, Stetsenko \& Sharaia, 2018); forms of committing corrupt abuses of public finances (Sukhonos, Pavlenko, Krukhmal, Ivanovska \& Maletov, 2021), however, it is crucial what the relevant studies virtually avoid the analysis of developments in the regulation of lobbying at the municipal level, which is unacceptable for states in which financial decentralization is carried out.

An important role in the study of the analysis of the mechanisms of existence and functioning of corruption in modern society is played by the works of S. Rose-Ackerman, namely two options of the development of corruption: "bottom-up" and "top-down" (Rose-Ackerman, 2013).

\section{Methodology}

In the process of scientific research a set of philosophical and worldview, general scientific and special scientific methods was used. The axiological approach was used to clarify the role and importance of proper legal regulation of lobbying and to establish a contractual form of regulation of public relations that arises when lobbying for making government decisions at the municipal level. The method of analysis and synthesis facilitated the analysis of the concept, features, object, parties and conditions of concluding a lobbying agreement. In the article we also used some special scientific research methods, namely systemic, structural-functional, and comparative-legal. Systematic and structural-functional method was used to establish the role and importance of lobbying in the process of law-making activities of the bodies of public authorities, to distinguish lobbying from corruption offenses; comparative-law method was used to compare legal concepts, phenomena and processes, to determine their general and special features, to clarify the correlation between lobbying and corruption; to study foreign experience in the legal regulation of lobbying, etc.

\section{Results and Discussion}

In many countries, lobbying issues are in some way regulated by law; at the same time, this process is still at an early stage of development in our country.

Extremely important, especially at the level of municipalities, is the optimal regulation of the degree of influence of lobbyists on law-making, law enforcement processes, on the activities of government institutions. In part, to solve this problem, such a method as legal planning will be useful, which allows by involving professional scientific community to predict the consequences of the implementation of certain measures to regulate lobbying, to conduct a detailed study of relevant measures and processes both in statics and in dynamics. Also, legal planning is an integral method of implementing legal policy and the implementation of legal life, which will allow to make the right emphasis in the study of legal relations in the sphere of lobbying.

With the implementation of the reform of decentralization of public power in Ukraine, more and more issues of local importance are regulated in municipal legal acts (Halus, 2017). The municipal reform initiated the process of forming effective local self-government and territorial organization of power in order to create and maintain a full value living environment for citizens, provide high quality and affordable public services, establish institutions of direct democracy, meet the interests of citizens in all spheres of vital activity in the relevant territory, coordination of the interests of the state and territorial communities. The legal regulation of local self-government relations, which also takes place at the municipal level, plays an important role in this process (Halus, 2019). The process of municipal-legal regulation is influenced by both objective and subjective factors. The objective factors do not depend on the will of the subject of municipal law-making and are determined by historical, national-cultural, socio-economic, geographical and other features of making local self-government in the territorial community. The subjective factors depend on the will of the subject of municipal law-making. These can be such phenomena as political confrontation, lack of political will, lobbying, corruption, and so on.

Various institutions of civil society, enterprises, organizations and others are involved in the decision-making process of local selfgovernment bodies. Since the procedure for initiating issues submitted to local governments is only superficially prescribed in the regulations 


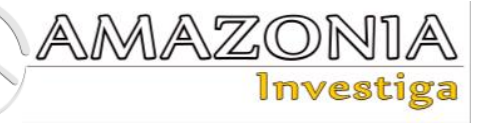

of their activities, lobbying leads to the fact that in their decisions local governments do not rely on the interests of the local community (or common interests of local communities), but other public, often corporate or political interests.

Yu. Hanzhurov rightly singles out 3 types of lobbying activities: the first type is actually lobbying activity (direct lobbying), when purposeful work is carried out with the representatives of government institutions to achieve a certain goal. The second type is indirect lobbying, when events are organized in the form of large-scale actions in the media, petitioning, and other public methods of forming public opinion as a means of putting pressure on the authorities, especially parliament. Finally, the third type is internal lobbying, when certain interests in governmental bodies are protected by those who work in them or have direct access to them (Hanzhurov, 2005). These types of lobbying can also be distinguished in relation to local self-government bodies.

Direct lobbying for making government decisions at the municipal level can also be expressed in the direct exercise of the right of certain subjects in their interests to initiate consideration of certain issues. Thus, the Law of Ukraine "On Local Self-Government in Ukraine" in section 13 of the article 46 stipulates that proposals on issues for consideration by the council may be submitted by the village, settlement, city mayor, standing commissions, deputies, executive committee of the council, head of local state administration, head of district, regional council, general meeting of citizens. Section 8 of this article contains a provision that the session of the council is convened to consider the electronic petition that has received the required number of signatures, within the period established for its consideration.

At the municipal level, these issues are also regulated, in particular, at the level of regulations of local councils and executive committees of local councils. In them, bodies of local governments can determine additional range of subjects of municipal law-making initiative.

In this case, direct lobbying by citizens members of the local community decisionmaking by local governments can be seen as a manifestation of local direct (immediate) democracy, which can take the form of local initiatives, public hearings, general meetings of citizens at the place of their residence, e- petitions, appeals of citizens (petitions), peaceful assemblies, etc.

If direct lobbying is carried out by the bodies of public authorities, other bodies of local selfgovernment, their officials, it is necessary to distinguish whether they have this right at the constitutional and legislative levels. After all, in accordance with article 19 of the Constitution of Ukraine, bodies of public authority and bodies of local self-government, their officials are obliged to act only on the basis, within the powers and in the manner prescribed by the Constitution and laws of Ukraine. Thus, in particular, the Law of Ukraine "On Local Self-Government in Ukraine" establishes the norm that proposals on the issues for consideration by the council can be submitted only by the village, settlement, city mayor, standing commissions, deputies, executive committee of the council, head of local state administration, head of the district, regional council. In other cases, we can talk about the illegal interference of other bodies of public authority, their officials in the activities of local self-governments, which would be a violation of the principle of their legal independence enshrined in the European Charter of Local SelfGovernment.

Actions of a public authority official who abuses power or official position by lobbying a local government for a decision in his / her favour, i.e. intentionally uses power or official position against his / her interests in order to obtain any illegal benefit for themselves or another person services, if it caused significant damage, should be classified as a crime under the article 364 of the Criminal Code of Ukraine - abuse of power or official position.

Indirect lobbying of making government decisions at the municipal level is to carry out activities to promote government decisionmaking by stakeholders indirectly, i.e. through other bodies of public authority, civil society institutions and more. For this purpose, illegitimate (not reflecting the real will of their members) paid peaceful assemblies, information campaigns in the media, social networks, etc. can be held in order to encourage local governments to make certain decisions.

If an official of a public authority proposes or promises (agrees) for improper benefit to themselves or a third party to influence the decision-making person authorized to perform the functions of local self-government, then these actions should be classified as a crime - abuse of 
influence under the article $369-2$ of the Criminal Code of Ukraine.

Internal lobbying for making government decisions at the municipal level can take place when certain interests in local governments are protected by those who work for them or have direct access to them. So, for example, it can be manifested in illegal influence of the village, settlement, city mayor on deputies of local council, members of executive committee of council, or at illegal influence of the municipal employee of executive body of local council on decision-making by this body, etc.

Actions of such officials of a local selfgovernment body, which lobbies for the adoption of an authoritative decision by the body in its favour, abuses power or official position, i.e. intentionally uses power or official position against the interests of the service, if it caused significant damage, should be classified as a crime under the article 364 of the Criminal Code of Ukraine - abuse of power or official position.

Therefore, in order to prevent illegal actions, including corruption offenses, in promoting local self-government decision-making, lobbying should be legally defined as only direct, legitimate cooperation of local governments with professional lobbyists.

We agree with I.V. Bovsunivska, who claims that lobbying as a complex political process has positive and negative sides. The boundary between them can be drawn only in a legislative way (Bovsunivska, 2019). The Anti-Corruption Strategy for 2014-2017 and the draft AntiCorruption Strategy for 2020-2024 enshrined the legislative regulation of lobbying in Ukraine as one of the expected results.

Lobbying of the process of adoption of legal acts by the bodies public authority in Ukraine is not regulated at the constitutional, legislative and bylaw levels. Four bills related to the issue of lobbying were submitted to the Verkhovna Rada of Ukraine of the last convocation, but three of them were returned to the subjects of the legislative initiative. It is worth agreeing with the drafters of the Law of Ukraine No. 3059-2 "On Legal and Transparent Regulation of Lobbying Activities", who in the explanatory note to it indicate that the recognition at the legislative level of lobbying, the introduction of the single register of lobbyists will make their activities transparent and regulated. Society will be able to openly demonstrate its market of lobbying services, expose "shadow" lobbyists, give them the opportunity to change the form of their activities, attract additional tax revenues (Law of Ukraine No. 3059-2, 2020).

It is extremely important that the process of legal regulation become bilateral. That is, the need to adopt a basic law that would, having an imperative character, establish a kind of "rules of the game" in the field of lobbying becomes fundamental. On the other hand, it is important to take into account the cultural, and, above all, economic characteristics of the community when lobbying its interests. At the municipal level, it is important to identify the following issues: the main problems of the community; what aspects of the problem can be solved through lobbying; methods of registration of persons engaged in lobbying, taking into account the wishes of stakeholders.

That is, the need for the adoption of the basic law, which would, having an imperative nature, establish a kind of "rules of the game" in the sphere of lobbying, becomes fundamental. On the other hand, it is important to take into account the cultural, and, above all, economic characteristics of the community when lobbying its interests. At the municipal level, it is important to identify the following issues: the main problems of the community; what aspects of the problems can be solved through lobbying; methods of registration of persons engaged in lobbying, taking into account the wishes of stakeholders. In order to effectively establish the lobbying process and to bring it to the legal level, it is necessary that persons interested in defending the interests of their client and aiming to establish contact with municipal authorities identified: themselves as the appropriate natural or legal person; entered into a duly registered lobbying agreement; in the contract specified what they pursue, addressing in the special body; what methods of influence they would like to use to achieve them; in favour of which subjects of legal relations the accepted lobbying decisions are affected.

Taking into account the fact that the legal system of the state is in a certain dynamics, there is the need to stabilize (establish) social relations, the emergence of which is due to the realities of today. One such new legal remedy is the agreement between a person who is interested in passing a law and a law firm to provide lobbying services.

In order to normalize such activities, it is advisable to think about the settlement of these relations in a contractual manner (Lytvyn, 


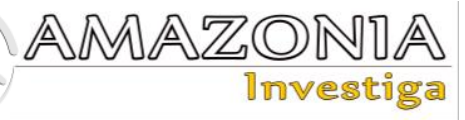

Zinchenko, Basarab, Andrusiv \& Ryzhuk, 2021), so between a lobbyist and a client who wants to influence making public decisions can be concluded agreements in accordance with the Civil Code of Ukraine (service contract). Such an agreement will be multilateral, as the parties will be a lobbyist (an entity that will provide lobbying services), a customer (a party wishing to obtain favourable amendments to a normative legal act or a normative legal act, which will enshrine in the desired manner public relations and undertake to pay for the services provided) and bodies of public authority, their officials who in legislative way will settle the issue.

The subject of the contract for the provision of lobbying services will be a service for lobbying the private interests of the customer, which will later be reflected in the normative legal act.

The forms of promotion (lobbying) of private interests in the authority can be the following: obtaining information from the bodies of public authority to assess the passage of the bill and the draft of another public decision; preparation of a draft of any normative legal act; risk analysis for the client of certain changes; promotion of the bill (assistance in issuing instructions and directives, initiating public hearings, public discussions, etc.); preparation and promotion of the expert opinion on the bill (initiating the creation of expert councils on topics that will be determined by the agreement); agitation for the client's position.

In general, civilized and open lobbying is quite acceptable. When adopting laws, the legislator not only can, but must listen to the voices of those whose interests will be enshrined in law.

"Clients" can hire lawyers and experts to represent their interests in communication with the legislator.

Taking into account the following provisions are important aspects: the parties should be informed that a person who publicly or not publicly advocates for changes to the law is a lobbyist and receives payment for the provision of their services from the client; the legislator should adhere to the principle of objectivity in making the draft law in such matters, etc.

In order to avoid corruption manifestations and in order to make the process of the lobbying at the municipal level public and transparent, the lobbying agreement should be understood as a multilateral agreement between the customer, lobbyist and local government, which has a public law nature, establishes contractual rules of lobbying influence on the process of making normative municipal-legal acts. Lobbying for the adoption of municipal-legal acts can also be manifested in lobbying for the conclusion by local self-governments of agreements on cooperation of territorial communities. The future law should also make it mandatory to publish such agreements on the official websites of local self-governments. Such a multilateral lobbying agreement, one of the parties to which is a local self-government body, should also be considered a municipal or municipal-law agreement (Halus, 2018).

Also, the current place in the bill should be given to the procedure of registration of lobbyists and their accreditation, they should not unreasonably eliminate people who want and intend to defend their interests at all levels of government, otherwise there will be no sense in these procedures. Accreditation of lobbyists, which is offered by various specialists, can serve as additional measure of control over the activities of stakeholders. Control will be expressed in the fact that the regulations on accreditation will establish: 1) the procedure for access of lobbyists to public authorities; 2) the procedure for interaction with elected representatives, officials who may act as subjects of lobbying; 3) the methods of obtaining information that may contain data and facts; 4) the ways of interfering in the process of creating and making appropriate government decisions. As a result, the registration and accreditation procedure will be simplified to the maximum, which will guarantee a number of additional rights granted to lobbyists.

However, foreign experience shows that, in general, it is impossible to defeat illegal lobbying. It exists even in countries where the legal limits of such acts have been established for a long time, where the established templates of lobbying agreements have been used for decades. That is, even in such countries as the United States or Germany, it is sometimes difficult to draw the line between illegal lobbying and corruption. However, there are ways to significantly reduce the impact of the shadow economy in such states. Firstly, it is necessary to determine which of the models of legislative consolidation of lobbying should be chosen by our state. The American system is quite rigid, requiring lobbyists to register and report on their activities. The European system provides only for voluntary registration of lobbying. In any case, most of the changes are to improve the legislation. It is necessary to significantly reduce 
the possibility of duplication, first of all, by-laws. This makes it possible to speed up or slow down legal processes that are not socially useful with the help of the courts. It is necessary to introduce mandatory practice of monitoring the repeal of previously existing regulations, on the bases of adoption of the new ones. It is necessary to deprive government officials of freedom of action in disposing of appropriate resources. In such cases, "room for manoeuvre" is artificially created in the exercise of their powers. It is then that the unspoken rule is realized: "Everything is for friends, the law is for enemies". As a result, the bureaucracy can nullify practically any solution that is useful for the state. It is necessary to reduce the number of state permits, which by the very fact of their existence create the likelihood of circumventing the illegal procedure. The above mentioned hinders market development, but contributes to corruption and illegal lobbying. Finally, it is necessary to adopt legislation regulating lobbying, as this will facilitate the fight against shadow lobbying, will allow to act legally (Bryhinets, Shapoval, Bakhaieva, Pchelin \& Fomenko, 2021). But with the appropriate revision of the legislation, of course, explicitly or implicitly, the relevant groups of influence will participate, so the likelihood of the emergence of new and revised laws for lobbyists is high. That is, this path is quite difficult and confusing.

When comparing lobbying and corruption, it should be understood that:

1) the subjects of lobbying and corruption are representatives of interests, on the one hand, and the public authority - on the other. The difference is that a lobbyist, unlike a person who provides illegal benefit, represents usually someone else's interest. But it is quite acceptable when a lobbyist can defend in all ways his or her own interest (selfemployed lobbyists work for themselves);

2) the object of these relations is the content of a specific decision of the authorities. But if lobbying is traditionally focused on the lawmaking process, then bribery is mainly aimed at individual law enforcement;

3) regarding the content of the legal relationship, lobbying is a set of rights and responsibilities of a representative of interests and a public authority. There can be no question of the content of corrupt legal relations, given that bribery is prohibited by law, the violation of which entails the onset of legal liability;

4) the lobbyist carries out the activity on a professional basis. Of course, in practice there are "professional intermediaries" in corruption, but their professionalism is factual, not legal;

5) both activities are regulated by law, but their legal mediation pursues different goals. In the case of lobbying, the legislator seeks to determine the order of registration and reporting, rights and responsibilities, requirements for the behaviour of lobbyists, liability for violations, and so on. In the case of bribery, the legislator seeks to reduce the number of facts of its commission;

6) The main difference between lobbying and corruption is the methods used to promote interests. Some researchers believe that lobbying is distinguished from corruption by the legitimacy of advocacy. This argument is not convincing, as the person giving the wrongful benefit may also promote a legitimate interest. However, the methods he or she uses are always illegal. In contrast, lobbying is the promotion of legitimate interests in lawful ways.

T. Ninua (2012) rightly argues that lobbying in itself is not a corrupt activity, and can be legitimate and positive force when carried out honestly and transparently. It is worth agreeing with M. Martini (2013), who states that where lobbying is opaque and disproportionate, it can lead to administrative bribery and political corruption.

Lobbying and bribery are forms of promoting private interests in public authorities. The difference between them is in the methods used to achieve the set goals: lobbyists use legal methods, corrupt people use illegal ones.

It should be noted that funds as a tool to influence public authorities (officials) can be used by both lobbyists and bribers. The legality of such actions depends entirely on the position of the legislator, who determines, for example, the value of eligible gifts or the limits of election fees. This determines the fundamental importance of detailed regulation of lobbying activities, especially permitted methods of influencing public authorities.

The construction of legal norms under the illegal influence of lobbying structures creates favourable environment for corruption, increasing its level. In this case, corruption is a direct consequence of lobbying, having a direct connection with it.

We cannot agree with this statement, because the interests of government and business and the 


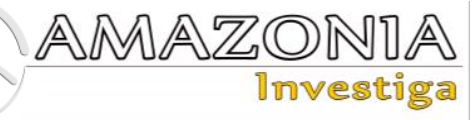

forms of their interaction today are so multifaceted that without intermediaries it is impossible to operate not only large but also medium-sized companies. Small businesses also need to protect their interests.

The most vivid and large-scale lobbying is manifested in the period of adoption of the budget of the appropriate level. This process develops according to the same scheme from year to year and is a reason to intensify the political struggle between different groups of influence (Bryhinets, 2014).

But due to the fact that lobbying is not currently regulated by law (i.e. there is no possibility of legal influence on the construction of legal norms), lobbyists have to balance on the verge of corruption.

The author of one of the most thorough studies on the relationship between lobbying and corruption, N.M. Kolosova (2014) proposes to introduce into scientific circulation and legislate the concept of "corruption lobbying", believing that this will give lobbying exclusively positive meaning.

The problem is that the concept of "lobbying" is not only not enshrined in law, but also not scientifically found an unambiguous interpretation (each scientist offers his or her own definition), there are frequent opinions about the nature and purpose of lobbying, its nature and social value. Therefore, the introduction of concepts in which one of the linguistic units of the phrase is "lobbyism" is unjustified; in this case it will create even more confusion in the concepts of "lobbying" and "corruption".

In this regard, S.V. Vasylieva (2013) rightly notes that "legislative policy in the sphere of lobbying is incorrectly associated with anticorruption reform. Regulation of lobbying and the fight against corruption are different areas that are better not to link.

Indeed, lobbying does not create corruption. Overcoming corruption is the subject of legislative regulation of political parties, elections, the status of public authorities and the civil service. And if within the framework of this legislation it is not possible to solve the problem of corruption, then within the framework of lobbying regulation it will not be possible to do so.

However, "anti-corruption policy will be incomplete without the legal institutionalization of lobbying" (Vasylieva, 2013). But the fragmentary nature of various manifestations, forms and methods of lobbying can lead to a significant increase in the number of normative legal acts, which are already many, unreasonable complication of legal relations, which by their nature are lobbying, and to the final destruction of the line between lobbying and corruption that, ultimately, will inevitably lead to the fact that the same act can be qualified both as the promotion of private interest and as the commission of a corruption offense.

\section{Conclusions}

The existing legal policy in our country is characterized by the dynamism of its existence, the search for new, more constructive methods of regulation. It is an extremely difficult and important task to properly predict the consequences of the adoption of the bill on lobbying regulation. Particular attention should be paid to the introduction of the new mechanism that will ensure the development of very specific legal relations. We should not forget that the legislator always reserves the right to properly intervene in the regulatory process, so the shortcomings, drawbacks of the bill will be immediately apparent, finding its reflection in practice.

There is no doubt that the legalization of lobbying will solve many problems, will become an important step towards the formation and development of civil society. Therefore, it is correct to conclude that the development of lobbying should be enshrined in legal norms, in improving the mechanisms of lobbying activity and its functions.

Legislation should define lobbying at the municipal level as direct, legitimate cooperation of the bodies of local government with professional lobbyists.

The agreement on lobbying at the municipal level is advisable to understand as the multilateral agreement between the customer, lobbyist and local self-government, which has a public-law nature, establishes contractual rules of law on lobbying to influence the process of adoption of municipal-legal acts.

The above mentioned actions will allow controlling lobbyists, who without discrediting, as rightly noted, the legislative process, the activities of government institutions, and, at the same time, reflecting information on the steps and intentions of lobbyists, will both identify 
community attitudes and provide solutions to the most urgent problems facing the community.

As a result, it is the modelling of the development and functioning of the legal mechanism for lobbying for the result that the state and its territorial entity need for the effective implementation of legal policy - should become a priority to improve the overall welfare of Ukrainian citizens. However, the implementation of lobbying legislation may reduce corruption, but the existence of informal contacts, especially at the municipal level, which cannot be controlled, will remain significant. The most important thing is the self-cleansing of the national elite, which will influence the local elites. It is then, due to the institutionalization of legal forms of lobbying, the level of corruption will decrease and reach the level typical of developed countries. However, such a scenario is possible only with favourable economic and political dynamics. Otherwise, we will face a catastrophic rise in corruption, grey and black lobbying schemes.

In Ukraine, as in many countries during their formation, lobbying and corruption are part of the processes taking place in the country. Sometimes they are even system-forming phenomena and slow down the sharp decline of the economy.

\section{Bibliographic references}

Bovsunivska, I.V. (2019). Summary of lectures on the subject "Lobbying in public authorities". K.: UkrSICH (51 p.). URL: http://tnu.edu.ua/sites/default/files/normativb asa/lobizmmet.pdf

Brown, H. (2012). Lobbying the new president. Interests intransition. N.Y.: Routledge, (218 p.).

Bryhinets, O., Shapoval, R., Bakhaieva, A., Pchelin, V., \& Fomenko, A. (2021). Problems of intellectual property in the national security system of the country. Entrepreneurship and Sustainability, No. 8(3), 471-486. URL: https://doi.org/10.9770/jesi.2021.8.3(30)

Bryhinets, O., Svoboda, I., Shevchuk, O., Kotukh, Ye., \& Radich, V. (2020). Public value management and new public governance as modern approaches to the development of public administration. Revista San Gregorio, 42. URL: http://revista.sangregorio.edu.ec/index.php/R EVISTASANGREGORIO/article/view/1568 /20-OLAKSANDR.
Bryhinets, O.O. (2014). The impact of corruption on the level of financial security of the state. Collection of scientific works of the National University of the State Tax Service of Ukraine, No. 2 (65), 10-14.

Draft Law of Ukraine No. 3059-2, "On legal and transparent regulation of lobbying activities". Verkhovna Rada de Ucrania, from 02.03.2020. URL: http://w1.c1.rada.gov.ua/pls/zweb2/webproc 4_1?pf3511=68275

Halus, O.O. (2017). The concept and types of municipal-legal acts. Constitutional and legal academic studies, No. 3, 26-32. URL: https://dspace.uzhnu.edu.ua/jspui/bitstream/l ib/30649/1/\%d0\%93\%d0\%b0\%d0\%bb\%d1 $\% 83 \%$ d1\%81\%20\%d0\%9e.\%20\%d0\%9e\%2 c.pdf

Halus, O.O. (2018). The concept and the features of municipal legal agreement. Constitutional and legal academic studies, No. 2, 114-118. URL:

https://dspace.uzhnu.edu.ua/jspui/bitstream/1 $\mathrm{ib} / 30777 / 1 / \% \mathrm{~d} 0 \% 9 \mathrm{f} \% \mathrm{~d} 0 \% 9 \mathrm{e} \% \mathrm{~d} 0 \% 9 \mathrm{~d} \% \mathrm{~d} 0 \%$ af\%d0\%a2\%d0\%a2\%d0\%af\%20\%d0\%a2\% d0\%90\%20\%d0\%9e\%d0\%97\%d0\%9d\%d0 $\% 90 \%$ d0\%9a\%d0\%98.pdf

Halus, O.O. (2019). To the Issue of Determining the Limits of Municipal Legal Regulation. University Scientific Notes, No. 69-70, 38-49.

Hanzhurov, Yu. (2005). Parliamentary lobbying in the context of political communication. Political management, No.4, 50-62.

Hunter, K. (2001). Analysis of the effect of lobbying efforts and demand-side economic development policies

on state economic health. Public Administration Quarterly, No. 25, 49-78.

Jenkins, M., \& Mulcahy, S. (2018). Businesses' lobbying practices. Transparency International Anti-Corruption Helpdesk Answer. (26 p.). URL: https://knowledgehub.transparency.org/asset s/uploads/helpdesk/Businesses-LobbyingPractices_2018.pdf

Kolomoets, T., Stetsenko, S., \& Sharaia, A. (2018). Gifts for a public servant: whether it is worth to comply with the rules. Baltic Journal of Economic Studies, 4(2), 106-113. URL:

http://www.baltijapublishing.lv/index.php/is sue/article/view/388/pdf

Kolosova, N. M. (2014). Lobbying and corruption. Journal of Russian Law, No. 2, 53-59. URL: https://cyberleninka.ru/article/n/lobbizm-ikorruptsiya-1 


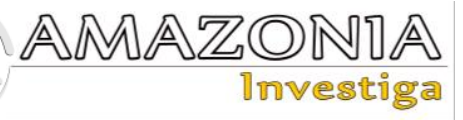

Kooiman, Ya. (2001). Social and political governance. Public administration. M.: Reference dictionary. 330-333.

Lazur, Ya., Karabin, T., Martyniuk, O., Bukhanevych, O., \& Kanienberh-Sandul, O. (2020). Ensuring a Balance Between Public and Private Interests in the Implementation of Quarantine Measures. Revista de Derecho, No. 9 (II), 317-340.

Lytvyn, S., Zinchenko, O., Basarab, O., Andrusiv, U., \& Ryzhuk, I. (2021). Legal regulation of the agreement on provision of tourist services during the pandemic covid19. Journal of Environmental Management and Tourism, No.12(2), 501-506.

Martini, M. (2013). Influence of Interest Groups on Policy-Making. Transparency International Helpdesk Answer. URL: https://www.u4.no/publications/influenceof-interest-groups-on-policy-making.pdf

Ninua, T. (2012). Best Practices in Regulation of Lobbying Activities. Transparency International Helpdesk Answer. URL: http://www.transparency.org/whatwedo/ans wer/best_practices_in_regulation_of_lobbyi ng_activities
Popovych, I., Shevchenko, A., Galvez, L. M., \& Klenina, K. (2020). Estudio de la relación entre la deseabilidad social y las orientaciones valorativas de los jóvenes. Revista Notas Históricas y Geográficas, No. 26, pp. 241-268.

Rose-Ackerman S. (2013). Corruption and the state: causes, consequences, reforms: a book. Moscow: Norma-Infra-M, (356 p.).

Savchenko, L., Subbot, A., \& Demianchuk, Yu. (2018). Influence of corruption on the economic development of Ukraine in terms of reformation: a retrospective analysis. Baltic Journal of Economic Studies, 4(3), 276-282.

Sukhonos, V., Pavlenko, L., Krukhmal, O., Ivanovska, A., \& Maletov, D. (2021). Forms of committing corrupt abuses of public finances and ways to counteract them in Ukraine. Amazonia Investiga, 10(39), 149-158.

https://amazoniainvestiga.info/index.php/am azonia/article/view/1581

Vasylieva, S.V. (2013). Legal institute of lobbying in Russia: assessment of legislation and prospects of formation. Comparative Constitutional Review, No.1, 136-148. 